\title{
REDUCTION OF GLYCOALKALOIDS IN POTATO UNDER THE INFLUENCE OF BIOSTIMULATORS
}

\author{
MYSTKOWSKA, I. \\ State School of Higher Education, Sidorska 95/97, 21-500 Biała Podlaska, Poland \\ (e-mail: imystkowska@op.pl) \\ (Received 30 $0^{\text {th }}$ Nov 2018; accepted $14^{\text {th }}$ Feb 2019)
}

\begin{abstract}
The aim of the conducted research was to determine the effect of biostimulators on the content of glycoalkaloids in leaves and tubers of three edible potato varieties. The experiment was established in a split-plot system in three replications. The examined factors were: I - three varieties of edible potato: Honorata, Jelly, Tajfun, and II - five types of using biostimulators: biostimulator BrunatneBio Złoto Cytokinin $^{\circledR}$, GreenOk ${ }^{\circledR}$, Kelpak SL ${ }^{\circledR}$, Titanit ${ }^{\circledR}$, control variant. In the biostimulators group there were products containing functional elements, eg titanium, products based on algae extracts, and products containing amino acids. The lowest concentration of glycoalkaloids in leaves and tubers of edible potato was found in the Jelly variety $-251 \mathrm{mg} \cdot \mathrm{kg}^{-1}$ on average in leaves, and $-80.5 \mathrm{mg} \cdot \mathrm{kg}^{-1}$ in tubers, while the largest in the Tajfun variety - on average in leaves $370 \mathrm{mg} \cdot \mathrm{kg}^{-1}$, in tubers $110 \mathrm{mg} \cdot \mathrm{kg}^{-1}$. Under the influence of all bioregulators, there was a significant reduction in the content of harmful glycosides as compared to the control variant. The lowest concentration was recorded under the influence of the BrunatneBio Złoto biostimulator - on average in the leaves $293 \mathrm{mg} \cdot \mathrm{kg}^{-1}$, in tubers $91 \mathrm{mg} \cdot \mathrm{kg}^{-1}$.
\end{abstract}

Keywords: Solanum tuberosum L., glycosides, BrunatneBio Złoto Cytokinin ${ }^{\circledR}$, GreenOk ${ }^{\circledR}$, Kelpak $S L^{\circledR}$, Titanit $^{\circledR}$

\section{Introduction}

Glycoalkaloids (TGA - total glycoalkaloids) are toxic steroid glycosides naturally occurring in a potato plant (Solanum tuberosum) (Friedman, 2006). In leaves, stems, flowers and sprouts, the content of these compounds is several times higher than in tubers. The maximum content of glycoalkaloids, regardless of the variety, is up to 200 $\mathrm{mg} \cdot \mathrm{kg}^{-1}$ of fresh tuber weight (Mazurczyk and Lis, 2000; Barceloux, 2008). In the studies of many authors (Mazurczyk and Lis, 2000; Percival and Dixon, 1997; Lachman et al., 2001), the total content of glycoalkaloids (cTGA; content of total glycoalkaloids) in potato tubers usually ranged from 10 to $150 \mathrm{mg} \cdot \mathrm{kg}^{-1}$ of fresh weight. Wroniak and Mazurczyk (2006), on the basis of many years of research between 1988-2005, including studying 145 varieties showed that fluctuations in the content of glycoalkaloids constituted from 3 to $350 \mathrm{mg} / \mathrm{kg}$ of fresh tuber mass. TGA accumulation in tubers above $100 \mathrm{mg} \cdot \mathrm{kg}^{-1}$ of fresh mass causes significant deterioration if taste (Mazurczyk and Lis, 2000), reducing their nutritional value and may also adversely affect human health. Consumption of potatoes with excessive content of glycoalkaloids may be toxic, damaging the nervous system and cause gastrointestinal disorders (Friedman and Dao, 1992; Percival et al., 1996). According to Grenda (2003), Pusz and Pląskowska (2008), Von Bennewitz Alvarez et al. (2008), Matysiak et al. (2011) and Bulgari et al. (2015) biostimulators used in the cultivation of plants are a natural method of better utilization of plant growth conditions (temperature, air and substance humidity, amount and intensity of light) and nutrients, which in turn contributes to the increase in the quantity and quality of the crop.

Our hypothesis was that the use of biostimulators reduce the concentration of glycoacaloids in potatoes. Here we present the impact of the types of biostimulators on 
the content of anti-nutritional compounds called glycoalkaloids in leaves and tubers of three edible potato varieties.

\section{Materials and methods}

\section{The experimental site}

Field research was carried out from 2015 to 2017 in an individual farm in

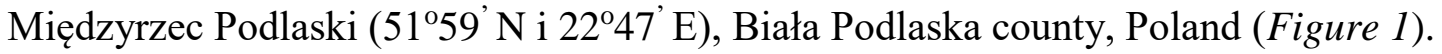

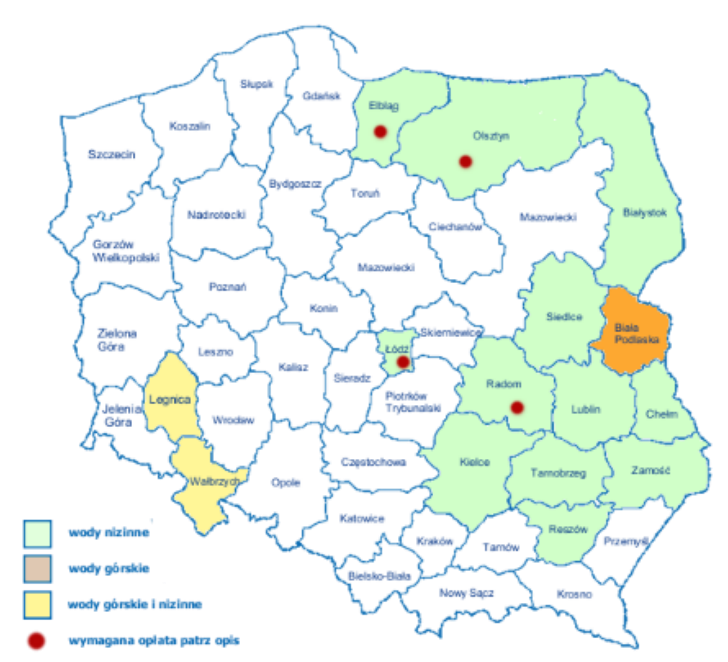

Figure 1. Location of the experiment

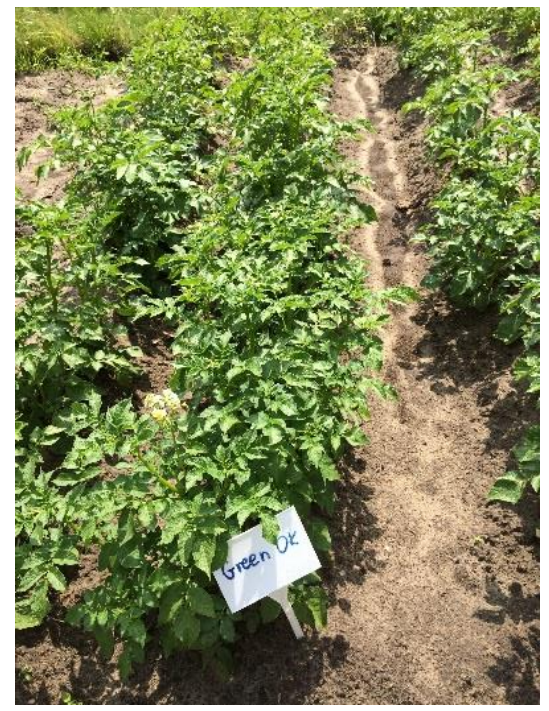

The experiment was established in three replications using the split-plot method, on the soil included in the very good rye complex, of the IV a soil class. In individual years of research, soils differed in the content of organic matter and available macro-elements. In 2015 and 2016, the soil was characterized by slightly acidic reaction, and in the last year of research, alkaline. The content of organic matter ranged from 15.0 to $18.7 \mathrm{~g} \cdot \mathrm{kg}^{-}$ 1. The content of available phosphorus $(\mathrm{P})$ was from high to very high, potassium $(\mathrm{K})$ from medium to very high, and magnesium $(\mathrm{Mg})$ was high. The first factor were three moderately early varieties of edible potato: Honorata, Jelly and Tajfun, and the second one, four types of biostimulators used in three dates (beginning of flowering, fully flowering and after flowering of plants):

- Control variant - without the use of biostimulators spraying with distilled water.

- Biostimulator BrunatneBio Złoto (active substances - plant hormones: auxin $0.06 \mathrm{mg} \cdot \mathrm{l}^{-1}$ and cytokinin - $\left.12 \mathrm{mg} \cdot \mathrm{l}^{-1}\right)$ at a dose of $0.20 \mathrm{l} \cdot \mathrm{ha}^{-1}$.

- Biostimulator GreenOk ${ }^{\circledR}$ (active substance - humus substances $20 \mathrm{~g} \cdot \mathrm{l}^{-1}$ ) at a dose of $0.201 \cdot \mathrm{ha}^{-1}$.

- Biostimulator Kelpak ${ }^{\circledR}$ SL (active substance - Ecklonia maxima algae extract), containing plant hormones: auxin $-11 \mathrm{mg} \cdot \mathrm{l}^{-1}$ and cytokinin $-0.031 \mathrm{mg} \cdot \mathrm{l}^{-1}$, at a dose of $0.201 \cdot \mathrm{ha}^{-1}$.

- Biostimulator Tytanit ${ }^{\circledR}$ (active substance - titanium) at a dose of $0.201 \cdot$ ha $^{-1}$. 
The forecrop for potato in particular years of research was winter wheat. After harvesting the forecrop, a team of post-harvest crops was made. In autumn, each year preceding planting, organic fertilization in the form of manure in the amount of 25.0 $\mathrm{t} \cdot \mathrm{ha}^{-1}$ and mineral fertilization with phosphorus-potassium in the amount of $\mathrm{P}-44.0$ $\left(100 \mathrm{P}_{2} \mathrm{O}_{5} \cdot 0.44\right) \mathrm{kg} \cdot \mathrm{ha}^{-1}$ (lubofos for potatoes $7 \%$ ) and $\mathrm{K}-124.5\left(150 \mathrm{~K}_{2} \mathrm{O} \cdot 0.83\right) \mathrm{kg} \cdot \mathrm{ha}^{-1}$ (lubofos for potatoes 25\%) was applied. These fertilizers were plowed pre-season plowing. Nitrogen fertilizers were applied in the spring in an amount of N $100 \mathrm{~kg} / \mathrm{ha}$ (nitro-chalk 27\%) and mixed with the soil using a cultivator. Potatoes were planted manually under the marker at a spacing of $67.5 \times 37 \mathrm{~cm}$, in the third decade of April (2015, 2016, 2017). Each plot with an area of $15 \mathrm{~m}^{2}$ accounted of five ridges. Cultivation and care treatments were carried out in accordance with the requirements of correct. During the growing season, the potato plantation was protected with the following incidences: Actara $25 \mathrm{WG}$ (thiametoksam) at the rate of $0.08 \mathrm{~kg} \cdot \mathrm{ha}^{-1}$ and Caliypso $480 \mathrm{SC}$ (thiacloprid) at the rate of $0.11 \cdot \mathrm{ha}^{-1}$, and fungicides: Copper Max New $50 \mathrm{WP}$ at the rate of $2.0 \mathrm{~kg} \cdot \mathrm{ha}^{-1}$ and Dithane Neo Tec $75 \mathrm{WG}$ the rate of $2.0 \mathrm{~kg} \cdot \mathrm{ha}^{-1}$. Samples of potato leaves (10 leaves from central part of a stalk) for chemical analyses were taken from each treatment at the flowering stage in July (after chemical treatments). Samples of potato tubers (50 tubers) were taken from each of the plots during harvest and stored at $10-12^{\circ} \mathrm{C}$, for 8-10 days. Chemical analyses were performed using fresh material from 10 representative tubers in three replications. The content of glycoalkaloids in leaves and tubers of potatoes was determined by the Bergers colorimetric method (Bergers, 1980). Fresh potatoes were homogenized; then, $150 \mathrm{ml}$ of ethanol were added to a $50 \mathrm{~g}$ sample and extraction in a water bath was performed at $90^{\circ} \mathrm{C}$. , the filtered extract was evaporated at $60^{\circ} \mathrm{C}$ using a rotary evaporator to the volume of $5 \mathrm{ml}$. After addition of $50 \mathrm{ml}$ of $10 \%$ acetic acid and centrifuging, the liquid part was poured into a flask, the sediment was poured to the supernatant (solution above the sediment) and $4 \mathrm{ml}$ of ammonia were added $\left(\mathrm{NH}_{3}\right)$ to adjust to $\mathrm{pH}=10$ The flask was heated in a water bath $\left(70^{\circ} \mathrm{C}\right)$ for $20 \mathrm{~min}$, then cooled at $4{ }^{\circ} \mathrm{C}$ for $3 \mathrm{~h}$ and centrifuged. The sediment was dissolved in $5 \mathrm{ml} 7 \%$ phosphoric acid $\left(\mathrm{H}_{3} \mathrm{P} \mathrm{O} \mathrm{O}_{4}\right)$. Next, $0.2 \mathrm{ml}$ of the solution were mixed with $2 \mathrm{ml}$ of $85 \%$ phosphoric acid with paraformaldehyde $\left(30 \mathrm{mg} \cdot \mathrm{l}^{-1}\right)$ and mixed again. After $40 \mathrm{~min}$, absorption was recorded at the wavelength of $600 \mathrm{~nm}$ (solution colour changes to blue and then gets lighter). The amount of potato total glycoalkaloids was calculated based on the L-solanine standard curve. The results of the analyses are given as $\mathrm{mg}$ per $1 \mathrm{~kg}$ of fresh matter.

Table 1. Weather conditions during of potato vegetation [Zawady Meteorological Station, $\left(52^{\circ} 03^{\prime} \mathrm{N}\right.$ and $\left.22^{\circ} 33^{\prime} \mathrm{E}\right)$, Poland]

\begin{tabular}{|c|c|c|c|c|c|c|c|c|}
\hline \multirow{3}{*}{ Months } & \multicolumn{4}{|c|}{ Air temperature $\left({ }^{\circ} \mathrm{C}\right)$} & \multicolumn{4}{|c|}{ Rainfall (mm) } \\
\hline & \multirow{2}{*}{$\begin{array}{c}\begin{array}{c}\text { Multi-year } \\
\text { mean }\end{array} \\
1996-2010 \\
\end{array}$} & \multicolumn{3}{|c|}{ Monthly means } & \multirow{2}{*}{$\begin{array}{c}\begin{array}{c}\text { Multi-year } \\
\text { mean }\end{array} \\
1996-2010 \\
\end{array}$} & \multicolumn{3}{|c|}{ Monthly sums } \\
\hline & & 2015 & 2016 & 2017 & & 2015 & 2016 & 2017 \\
\hline April & 8.0 & 8.2 & 9.1 & 6.9 & 33.6 & 30.0 & 28.7 & 59.6 \\
\hline May & 13.5 & 12.3 & 15.1 & 13.9 & 58.3 & 100.2 & 54.8 & 49.5 \\
\hline June & 17.0 & 16.5 & 18.4 & 17.8 & 59.6 & 43.3 & 36.9 & 57.9 \\
\hline July & 19.7 & 18.7 & 19.1 & 16.9 & 57.5 & 62.6 & 35.2 & 23.6 \\
\hline August & 18.5 & 21.0 & 18.0 & 18.4 & 59.9 & 11.9 & 31.7 & 54.7 \\
\hline September & 13.5 & 14.5 & 14.9 & 13.9 & 42.3 & 47.1 & 13.6 & 80.1 \\
\hline $\begin{array}{c}\text { April - } \\
\text { September }\end{array}$ & 15.0 & 15.2 & 15.8 & 14.6 & 335.4 & 295.1 & 200.9 & 335.4 \\
\hline
\end{tabular}




\section{Meteorological conditions}

In the years of research, varied weather conditions prevailed (Table 1). The growing season of 2015 proved to have an average of air temperature of $15.2^{\circ} \mathrm{C}$, higher by $0.2^{\circ} \mathrm{C}$ than the long-term mean and precipitation of $295.1 \mathrm{~mm}$. The highest average air temperature was recorded in 2016 and it amounted to $15.8^{\circ} \mathrm{C}$, it was higher than the long-term average by $0.8^{\circ} \mathrm{C}$, while this year was characterized by the lowest precipitation - $200.9 \mathrm{~mm}$, lower by $134.5 \mathrm{~mm}$ from the long-term sum. The highest number of rainfall was recorded in the growing season $2017-325.4 \mathrm{~mm}$ and the lowest average air temperature $-14.6^{\circ} \mathrm{C}$.

\section{Statistical analysis}

Results of the study were analysed by ANOVA. Significance of sources of variation was checked with the Fisher-Snedecor test and the significance of differences between means was tested using the multiple comparison Tukey's test at the significance level of $\mathrm{P}=0.05$. Statistical calculations were performed in Excel using the authors' own algorithm based on the split-plot mathematical model.

\section{Results and discussion}

The content of glycoalkaloids in potato tubers depending on the types of biostimulators used (Table 2). Statistical evaluations showed a significant effect of cultivars on the content of glycoalkaloids in potato tubers. The TGA content was the highest in the Tajfun variety, an average of $109.7 \mathrm{mg} \cdot \mathrm{kg}^{-1}$, and the lowest in the Jelly variety, an average of $80.5 \mathrm{mg} \cdot \mathrm{kg}^{-1}$. The results are similar to the results presented by Eltayeb et al. (2003), Hamouz et al. (2014) and Valcarcel et al. (2014), who stated that the genotype had a dominant effect on the content of glycoalkaloids in potato tubers. The biostimulators used in the experiment reduced the content of glycoalkaloids in tubers compared to the control. The lowest TGA concentration was noted in tubers from variants sprayed with the BrunatneBio Złoto biostimulator (variant 5), an average of $91.3 \mathrm{mg} \cdot \mathrm{kg}^{-1}$. In the studies by Zarzecka et al. (2015), there was an increase in glycoalkaloids after application with herbicide and biostimulator. While Hamouz et al. (2004; 2005) and Wierzbicka (2014) observed a trend towards increased TGA accumulation in edible potato tubers.

Table 2. Total glycoalkaloid content in potato tubers $\mathrm{mg} \mathrm{kg}^{-1}$ fresh matter

\begin{tabular}{c|c|c|c|c|c|c|c}
\hline \multirow{2}{*}{$\begin{array}{c}\text { Types of biostimulators } \\
\text { (variants) }\end{array}$} & \multicolumn{3}{|c|}{ Cultivars } & \multicolumn{3}{c|}{ Years } & \multirow{2}{*}{ Mean } \\
\cline { 2 - 7 } & Honorata & Jelly & Tajfun & $\mathbf{2 0 1 5}$ & $\mathbf{2 0 1 6}$ & $\mathbf{2 0 1 7}$ & \\
\hline 1. Control variant & $85.5 \mathrm{a}$ & $81.5 \mathrm{a}$ & $110.3 \mathrm{a}$ & $92.6 \mathrm{a}$ & $91.2 \mathrm{a}$ & $93.5 \mathrm{~b}$ & $92.4 \mathrm{a}$ \\
2. Kelpak SL & $84.8 \mathrm{~b}$ & $80.5 \mathrm{~b}$ & $109.8 \mathrm{~b}$ & $91.8 \mathrm{~b}$ & $90.4 \mathrm{~b}$ & $93.3 \mathrm{~b}$ & $91.8 \mathrm{~b}$ \\
3. Tytanit & $84.9 \mathrm{~b}$ & $80.7 \mathrm{~b}$ & $109.7 \mathrm{~b}$ & $91.6 \mathrm{bc}$ & $90.3 \mathrm{bc}$ & $93.5 \mathrm{~b}$ & $91.7 \mathrm{~b}$ \\
4. GreenOk & $84.9 \mathrm{~b}$ & $80.2 \mathrm{c}$ & $109.4 \mathrm{c}$ & $91.3 \mathrm{c}$ & $90.0 \mathrm{c}$ & $93.5 \mathrm{~b}$ & $91.5 \mathrm{c}$ \\
5. BrunatneBio Złoto & $84.8 \mathrm{~b}$ & $79.8 \mathrm{~d}$ & $109.3 \mathrm{c}$ & $90.7 \mathrm{~d}$ & $89.4 \mathrm{~d}$ & $93.9 \mathrm{a}$ & $91.3 \mathrm{~d}$ \\
Mean & $85.0 \mathrm{c}$ & $80.5 \mathrm{~b}$ & $109.7 \mathrm{a}$ & $91.6 \mathrm{~b}$ & $90.2 \mathrm{c}$ & $93.5 \mathrm{a}$ & 91.8 \\
\hline
\end{tabular}

Explanation: cultivars $-\mathrm{a}$; variants $-\mathrm{b}$; years $-\mathrm{c}$

There are many changes in the literature confirming the growth of TGA in tubers during the growing season due to stress conditions such as too low or too high 
temperature, prolonged cold or heat conditions, lack of water or its excess, and strong sunlight (Sinden et al., 1984; Bejarano et al., 2000; Hamouz et al., 2014). The cooperation of years and used biostimulators has been proved, which indicates a different effect of the biostimulators in changing climatic conditions during the tests (Table 2). Under the influence of the BrunatneBio Złoto biostimulator in the growing season 2015-2016, the lowest TGA concentration in tubers was obtained - on average from 90.2 to $91.6 \mathrm{mg} \cdot \mathrm{kg}^{-1}$, while in 2017 under the influence of Kelpak SL biostimulator, the lowest concentration of glycoalkaloids was obtained, on average 93 $\mathrm{mg} \cdot \mathrm{kg}^{-1}$. Weather conditions during the study years differentiated the level of glycoalkaloids in potato tubers. The least glycoalkaloids were found in 2016 with the highest average air temperature of $15.8^{\circ} \mathrm{C}$ and were higher than the long-term average of $0.8^{\circ} \mathrm{C}$, this year characterized by the lowest precipitation $-200.9 \mathrm{~mm}$, lower by 134.5 $\mathrm{mm}$ from the multiannual sum. The interaction of years with varieties confirmed the different accumulation of TGA in the years of research. Most TGA was found in three studied varieties in 2017, and the least in 2016 (Table 4). Similar results were described by Morris and Petermann (1985).

The content of glycoalkaloids in potato leaves depending on the types of biostimulators used (Table 3). The lowest concentration of glycoalkaloids in potato leaves was found in the Jelly variety - an average of $251 \mathrm{mg} \cdot \mathrm{kg}^{-1}$ and the largest in the Tajfun variety - an average of $370 \mathrm{mg} \cdot \mathrm{kg}^{-1}$. The content of glycoalkaloids in potato leaves was three times higher than in tubers. Zaczecka et al. (2015) in her studies found that the content was ten times higher in leaves than tubers, while Uppal (1987) and Żołnowski (2001) showed a 40-50 times higher concentrations in leaves compared to potato tubers. Biostimulators used in the experiment reduced the glycoalkaloids content in the potato leaves as compared to the control object. The smallest concentration of these compounds in potato leaves was obtained on plots sprayed with the BrunatneBio Złoto biostimulator (average of $293.5 \mathrm{mg} \cdot \mathrm{kg}^{-1}$ ). Other authors (Gugała et al., 2016) in relation to potato, using herbicides in combination with biostimulators (Harrier $295 \mathrm{ZC}$ $2.01 \cdot \mathrm{ha}^{-1}+$ Kelpak SL $2.01 \cdot \mathrm{ha}^{-1}$ and Sencor 70WG $1.0 \mathrm{~kg} \cdot \mathrm{ha}^{-1}+$ Asahi SL $1.0 \mathrm{l} \cdot \mathrm{ha}^{-1}$ ) received an increased concentration of glycoalkaloids in leaves and tubers in relation to the control plot.

Table 3. Total glycoalkaloid contents in potato leaves $\mathrm{mg} \cdot \mathrm{kg}^{-1}$ fresh matter

\begin{tabular}{c|c|c|c|c|c|c|c}
\hline \multirow{2}{*}{$\begin{array}{c}\text { Types of } \\
\text { biostimulators } \\
\text { (variants) }\end{array}$} & \multicolumn{3}{|c|}{ Cultivars } & \multicolumn{3}{c|}{ Years } & \multirow{2}{*}{ Mean } \\
\cline { 2 - 7 }$n$ & Honorata & Jelly & Tajfun & $\mathbf{2 0 1 5}$ & $\mathbf{2 0 1 6}$ & $\mathbf{2 0 1 7}$ & \\
\hline 1. Control variant & $266.1 \mathrm{a}$ & $252.6 \mathrm{a}$ & 371.6 & $296.7 \mathrm{a}$ & $293.7 \mathrm{a}$ & $299.9 \mathrm{a}$ & $296.8 \mathrm{a}$ \\
2. Kelpak SL & $262.6 \mathrm{~b}$ & $251.2 \mathrm{~b}$ & 369.8 & $292.0 \mathrm{~b}$ & $292.4 \mathrm{~b}$ & $299.2 \mathrm{ab}$ & $294.5 \mathrm{~b}$ \\
3. Tytanit & $263.7 \mathrm{c}$ & $250.9 \mathrm{~b}$ & 369.3 & $292.0 \mathrm{~b}$ & $292.1 \mathrm{bc}$ & $298.9 \mathrm{bc}$ & $294.2 \mathrm{~b}$ \\
4. GreenOk & $261.5 \mathrm{~d}$ & $250.2 \mathrm{c}$ & 369.0 & $290.8 \mathrm{c}$ & $291.6 \mathrm{~cd}$ & $298.3 \mathrm{c}$ & $293.6 \mathrm{c}$ \\
5.BrunatneBio Złoto & $261.2 \mathrm{~d}$ & $250.4 \mathrm{c}$ & 369.1 & $291.0 \mathrm{c}$ & $291.3 \mathrm{~d}$ & $298.2 \mathrm{c}$ & $293.5 \mathrm{c}$ \\
Mean & $263.0 \mathrm{~b}$ & $251.1 \mathrm{c}$ & $369.8 \mathrm{a}$ & $292.2 \mathrm{~b}$ & $292.2 \mathrm{~b}$ & $298.9 \mathrm{a}$ & 294.5 \\
\hline
\end{tabular}

Explanation: cultivars $-\mathrm{a}$; variants $-\mathrm{b}$; years $-\mathrm{c}$

Statistical evaluations showed the cooperation of varieties with the types of biostimulators used (Table 2). As a result of the use of biostimulators in the tested varieties, a significant reduction in the content of glycoalkaloids was observed. Regardless of the biostimulators used, the Jelly variety accumulated less of these 
compounds than the Honorata and Tajfun varieties. The cooperation of years and biostimulators used has been proven, which indicates different effects of the biostimulator in changing climatic conditions during the tests (Table 2). Under the influence of the BrunatneBio Złoto biostimulator in all growing seasons, the smallest TGA concentration was obtained - on average from 291 to $298.2 \mathrm{mg} \cdot \mathrm{kg}^{-1}$. Weather conditions in the study years differentiated the level of glycoalkaloids in potato leaves. The least glycoalkaloids were found in 2015, while the most of this component was accumulated by tubers in 2017, where the highest rainfall was recorded $-325.4 \mathrm{~mm}$ and the lowest average air temperature $-14.6^{\circ} \mathrm{C}$ (Table 4).

Table 4. Content of glycoalkaloids in fresh mass of edible potato tubers and leaves depending on the cultivars and years of conduct of tests $\left(\mathrm{mg} \mathrm{kg}^{-1}\right)$

\begin{tabular}{c|c|c|c|c|c|c}
\hline \multirow{2}{*}{ Cultivars } & \multicolumn{3}{|c|}{ Potato tubers } & \multicolumn{3}{c}{ Potato leaves } \\
\cline { 2 - 7 } & $\mathbf{2 0 1 5}$ & $\mathbf{2 0 1 6}$ & $\mathbf{2 0 1 7}$ & $\mathbf{2 0 1 5}$ & $\mathbf{2 0 1 6}$ & $\mathbf{2 0 1 7}$ \\
\hline Honorata & $85.0 \mathrm{~b}$ & $84.0 \mathrm{~b}$ & $86.2 \mathrm{~b}$ & $261.2 \mathrm{~b}$ & $257.8 \mathrm{~b}$ & $269.5 \mathrm{~b}$ \\
Jelly & $80.8 \mathrm{c}$ & $79.1 \mathrm{c}$ & $81.6 \mathrm{c}$ & $250.7 \mathrm{c}$ & $249.2 \mathrm{c}$ & $253.3 \mathrm{c}$ \\
Tajfun & $108.9 \mathrm{a}$ & $107.5 \mathrm{a}$ & $112.7 \mathrm{a}$ & $365.6 \mathrm{a}$ & $369.7 \mathrm{a}$ & $374.1 \mathrm{a}$ \\
\hline
\end{tabular}

Explanation: cultivars $-\mathrm{a}$; variants $-\mathrm{b}$; years $-\mathrm{c}$

In the present study, an interaction was observed between the varieties studied. The content of glycoalkaloids in potato leaves and tubers has a significant impact on the genetic characteristics of the variety, and weather conditions during the growing season. The use of four biostimulators contributed to the reduction in TGA in leaves and tubers of edible potato.

Summarizing, three varieties of edible potato grown in the study differed in terms of glycoalkaloid content in leaves and tubers. The lowest concentration of glycoalkaloids was found in the Jelly variety. Biostimulant BrunatneBio Gold reduced the content of glycoalkaloids in leaves and tubers of edible potato compared to the control. The weather conditions during the growing season of the potato crop can largely affect the content of glycoalkaloids in leaves and tubers of potato. The lowest content of glycoalkaloids in the leaves was found in the year 2015, and in tubers in the year 2016.

\section{Conclusions}

The use of four biostimulators contributed to the reduction in TGA in leaves and tubers of edible potato. Summarizing, three varieties of edible potato grown in the study differed in terms of glycoalkaloid content in leaves and tubers. The lowest concentration of glycoalkaloids was found in the Jelly variety. Biostimulant BrunatneBio Gold reduced the content of glycoalkaloids in leaves and tubers of edible potato compared to the control. The weather conditions during the growing season of the potato crop can largely affect the content of glycoalkaloids in leaves and tubers of potato. The lowest content of glycoalkaloids in the leaves was found in the year 2015, and in tubers in the year 2016. In the experiment discussed in this paper, TGA levels did not exceed 200 $\mathrm{mg} \cdot \mathrm{kg}^{-1}$ fresh weight of tubers. The three cultivars examined are thus safe for human consumption. 


\section{REFERENCES}

[1] Barceloux, D. G. (2008): Potatoes, tomatoes and solanine toxicity. - In: Barceloux, D. G. (ed.) Medical toxicology of natural substances: foods, fungi, medicinal herbs, toxicplants, venomous animals. Wiley, pp. 77-83.

[2] Bejarano, L., Mignolet, E., Devaux, A., Espinola, N., Carrasco, E., Larondelle, Y. (2000): Glycoalkaloids in potato tubers: The effect of variety and drought stress on the $\alpha$-solanine and $\alpha$-chaconine contents of potatoes. - Journal of the Science of Food and Agriculture 80: 2096-2100.

[3] Bergers, W. W. A. (1980): A rapid quantitative assay for solanidine glycoalkaloids in potatoes and industrial potato protein. - Potato Research 23: 105-110.

[4] Bulgari, R., Cocetta, G., Trivellini, A., Vernieri, P., Ferrante, A. (2015): Biostimulants and crop responses: a review. - Journal Biological Agriculture \& Horticulture 31(1): 117.

[5] Von Bennewitz Alvarez, E. A., Hlusek, J., Losak, T. (2008): Nutritional status, vegetative and generative behavior of apple trees after the application of two biopreparations. - Acta Universitatis Agriculturae et Silviculturae Mendelianae Brunensis 56(1): 13-18.

[6] Eltayeb, E. A., Al-Sinani, S. S., Khan, I. A. (2003): Determination of the glycoalkaloids $\alpha$-solanine and $\alpha$-chaconine levels in 18 varieties of potato (Solanum tuberosum L.) grown in Oman. - Potato Research 46: 57-66.

[7] Friedman, M., Dao, L. (1992): Distribution of glycoalkaloids in potato plants and commercial potato products. - J. Agric. Food. Chem. 40: 419-423.

[8] Grenda, A. (2003): Activator of metabolism processes. - Chemicals in Sustainable Agriculture 4: 263-269.

[9] Gugała, M., Zarzecka, K., Dołęga, H., Niewęgłowski, M., Sikorska, A. (2016): The effect of biostimulants and herbicides on glycoalkaloid accumulation in potato. - Plant, Soil and Environment 62: 256-260. doi: 10.17221/187/2016-PSE.

[10] Hamouz, K., Lachman, J., Dvořák, P., Pivec, V. (2004): Yield and quality of potatoes cultivated conventionally and ecologically. - Zeszyty Problemowe Postepów Nauk Rolniczych 500: 277-283.

[11] Hamouz, K., Lachman, J., Dvořák, P., Pivec, V. (2005): The effect of ecological growing on the potatoes yield and quality. - Plant, Soil and Environment 51: 397-402.

[12] Hamouz, K., Pazderů, K., Lachman, J., Orsák, M., Pivec, V., Hejtmánková, K., Tomášek, J., Čížek, M. (2014): Effect of cultivar, flesh colour, location and year of cultivation on the glycoalkaloid content in potato tubers. - Plant, Soil and Environment 60: 512-517.

[13] Lachman, J., Hamous, K., Orsak, M., Pivec, V. (2001): Potato glycoalkaloids and their plant protection and human nutrition - review. - Series Rotlinna Vyroba 47: 181-191.

[14] Matysiak, K., Adamczewski, K., Kaczmarek, S. (2011): Response of some crops cultivated in Great Poland to application of Asahi SL. - Progress in Plant Protection/Postępy w Ochronie Roślin 51(4): 1849-1857.

[15] Mazurczyk, W., Lis, B. (2000): The content of nitrates and glycoalkaloids in mature potato tubers. - Rocz. PZH 51(1): 37-41.

[16] Morris, S. C., Petermann, J. B. (1985): Genetic and environmental effects on levels of glycoalkaloids in cultivars of potato (Solanum tuberosum L.). - Food Chemistry 18: 271282.

[17] Percival, G. C., Dixon, G. R. (1997): Glycoalkaloids - In: D’Mello, J. P. F. (ed.) Handbook of plant and fungal toxicants. CRC Press, Baca Raton, New York: 19-35.

[18] Percival, G., Dixon, G. R, Sword, A. (1996): Glycoalkaloid concentration of potato tubers following exposure to daylight. - J. Sci. Food Agric. 71: 5.

[19] Pusz, W., Pląskowska, E. (2008): Effect of Asahi SL application on the health of winter rape plants. - Zeszyty Problemowe Postępów Nauk Rolniczych 531: 185-191. (In Polish)

[20] Sinden, S. L., Sanford, L. L., Webb, R. E. (1984): Genetic and environmental control of potato glycoalkaloids. - American Potato Journal 61: 141-156. 
[21] Trawczyński, C., Wierzbicka, A. (2011): The cultivar and environmental difference of glycoalkaloids content in potato tubers. - Biuletyn Instytutu Hodowli I Aklimatyzacji Roślin, 262: 119-126. (In Polish)

[22] Uppal, D. S. (1987): Varietal and environmental effect on the glycoalkaloid content of potato (Solanum tuberosum L.). - Plant Foods for Human Nutrition 37: 333-340.

[23] Valcarcel, J., Reilly, K., Gaffney, M., O'Brien, N. (2014): Effect of genotype and environment on the glycoalkaloid content of rare, heritage, and commercial potato varieties. - Journal Food Science 79: 1039-1048.

[24] Wierzbicka, A. (2014): The chemical composition of potato tubers grown on organic and conventional. - Ziemniak Polski 3: 24-29. (In Polish)

[25] Wroniak, J., Mazurczyk, W. (2006): Varied variation of glycoalkaloid content in the range from the average potato tuber weight. - Zesz. Probl. Post. Nauk Rol. 511: 189-195. (In Polish)

[26] Zarzecka, K., Gugała, M., Sikorska, A. (2015): The effect of herbicides on the content of glycoalkaloids in the leaves and tubers of potato. - Plant, Soil and Environment 61: 328331.

[27] Żołnowski, A. C. (2001): The effect of magnesium fertilization on glycoalkaloids content in leaves and tubers of potatoes. - Zeszyty Problemowe Postepów Nauk Rolniczych 480: 369-375. (In Polish) 